\title{
Morphology and ultrastructure of Sphaeromyxa noblei sp. n. (Myxozoa), parasite of Heteroclinus whiteleggii (Pisces) from Australian New South Wales coast
}

\author{
Jiří Lom \\ Institute of Parasitology, Academy of Sciences of the Czech Republic, Branišovská 31, 37005 České Budějovice, Czech \\ Republic
}

Key words: Sphaeromyxa noblei sp. n., ultrastructure, Myxosporea, Heteroclinus whiteleggii

\begin{abstract}
A new species, Sphaeromyxa noblei sp. n., is described from Heteroclinus whiteleggii (Perciformes: Clinidae), a marine fish from the coast of New South Wales in Australia. This raises the number of Sphaeromyxa species to 38; their list is presented. The species is characterised by a layer of branched glycostyles, which is about $2.4 \mu \mathrm{m}$ thick and is a feature rather unique in Myxosporea. Pansporoblasts form one or two spores. The study of ultrastructure of this species and of those described to date result in recognition of a combination of patterns characterising the genus: plasmodia have marked surface projections, the endoplasm is full of vacuoles larger than in any other myxosporean genus, and contains a special kind of cells, the lobocytes. Sections through polar capsule reveal different appearance of subsequent stretches of the polar filament unlike in other Myxosporea.
\end{abstract}

The genus Sphaeromyxa Thélohan, 1892 has included thus far 37 species, which have a rather peculiar morphology in that their polar filament is a flat ribbon folded several times back and forth instead of being tube-like and coiled in several turns like in all other myxosporeans. Sphaeromyxa species are coelozoic parasites of gallbladders of marine fish and form typically a large, flat plasmodium. Sphaeromyxa sabrazesi Laveran et Mesnil, 1900 was actually the first myxozoan to be investigated by the electron microscope (Grassé 1960). Since then, three species only of this genus were studied ultrastructurally (Lom 1969, Uspenskaya 1982, Gracia et al. 1997) although this genus offers interesting cytological features.

\section{MATERIALS AND METHODS}

The parasite was found in the gallbladder of Heteroclinus whiteleggii (Ogilby, 1894) (Perciformes: Clinidae) collected in September 1990 in the tide pools at the shore near the Arrawara biological station of the University of New England in Armidale, Australia. The station is situated $24 \mathrm{~km}$ north of Coffs Harbour at the New South Wales coast. The spores were observed, measured and photographed while fresh. The plasmodia were fixed for $60 \mathrm{~min}$ in cold $2 \%$ osmic acid in $0.1 \mathrm{M}$ cacodylate buffer and embedded in Epon-Araldite. Ultrathin sections were double stained with uranyl acetate and lead citrate and examined under a Philips 420 B electron microscope at $80 \mathrm{kV}$ accelerating voltage.

\section{RESULTS}

Sphaeromyxa noblei sp. $\mathrm{n}$.

Figs. 1-10

Gallbladders of two fish specimens out of four collected were infected. The average size of the leaf-like plasmodium $1 \times 0.5 \mathrm{~mm}$. The spores $20(18.5-21.5) \mu \mathrm{m}$ long (the straight distance between the tips of the arched spore), the thickness $5(4.8-5.2) \mu \mathrm{m}$, the width $5.6(5.2-$ 6) $\mu \mathrm{m}$. The elongate oval polar capsules $5.9(5-6.5) \mu \mathrm{m}$ long and $2.6(2.5-2.7) \mu \mathrm{m}$ wide; the ribbon-like polar filament folded twice longitudinally inside the capsule (Figs. 1, 2).

The surface of the shell valves with longitudinal ridges up to $1 \mu \mathrm{m}$ deep (as calculated from the transverse section in the TEM). As counted in the TEM from sectioned spores, the number of ridges at about midlength of the spore was 7 on one valve and 6 to 9 on the other.

\section{Ultrastructure}

The thickness of the plasmodium, as calculated from the TEM section, was about 70 to $80 \mu \mathrm{m}$. The plasmodium surface was covered with fine projections (Fig. 3 ), and from their tips extended ramified strands of mucus, forming together a network about $2.4 \mu \mathrm{m}$ thick (Fig. 4). The surface membrane, curiously enough, did not reveal any marked pinocytotic vesicles or canals.

The layer of the ectoplasm was homogeneous with some dense granules, was about $15 \mu \mathrm{m}$ thick, being rather sharply delimited from the endoplasm (Fig. 3). The ectoplasmic margin was full of various vesicles, mostly dense, and of mitochondria. At its peripheral layer, the endoplasm was full of dense vesicles and of vacuoles with granular content, in addition to a few developing spores. At the plasmodium centre, where it was thicker, the endoplasm was replete with large lucent vacuoles with rather straight boundaries with many interspersed vesicles, dark granules, mitochondria, vegetative nuclei of the plasmodium, generative cells and pansporoblasts (Figs. 4-6,8) with developing and mature spores. 


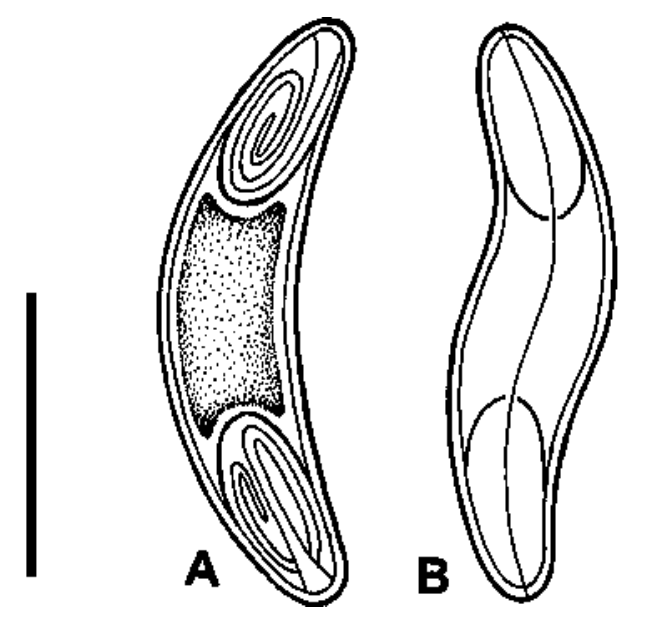

Fig. 1. Sphaeromyxa noblei $\mathrm{sp}$. n., line drawing of the spore in frontal (A) and sutural (B) view. Scale bar $=10 \mu \mathrm{m}$.

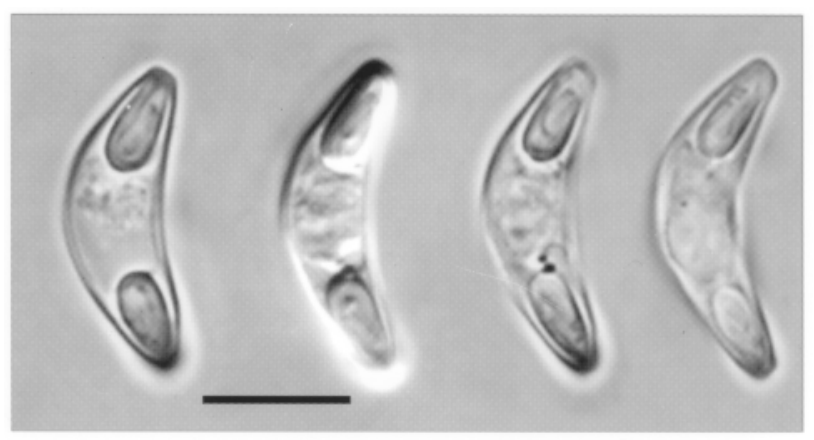

Fig. 2. Sphaeromyxa noblei sp. n., four spores photographed in fresh state and in frontal view. Scale bar $=10 \mu \mathrm{m}$.

As in other myxosporeans, the sequence of sporogonic cell divisions in the sporoblast could not be safely revealed; it was mostly the final stages of sporogenesis which could be observed. Curiously enough, while some pansporoblasts contained two spores (Fig. 5), the majority of pansporoblasts produced a single spore (Figs. 6, 8). In some pansporoblasts, next to a maturing spore there was a group of isolated cells, probably the result of an aborted sporogenesis.

Membrane of the pericyte cell persisted around the maturing spore, harbouring for some time still cell components like pericyte mitochondria and nucleus. The sporoplasm, occupying the space between the two capsules, had two large nuclei close to each other. The shell valves in a maturing spore had a condensed, darkappearing cytoplasm. In the grooves between the elevated ridges, there were approximately ten microtubules beneath the cell membrane (Fig. 8, arrow), which were no more visible in the completely dense, homogeneous shell valve of the mature spore. In the not yet mature spore, there was a thin, dense cap ("stopper" - Fig. 5, arrowhead) covering the flat discharge canal of the polar filament; this cap was not distinct in the mature spore.

At the sutures of the two shell valves, the borders of the valves did not face each other but overlapped each other. Thus one valve (the one which bore more ridges at mid-spore length) was fixed in the other one like in a cradle, which was especially evident near the tips of the spore (Fig. 6, arrowhead).

The nascent polar capsule, from which the external tube had already disappeared, contained dense matrix of a more or less homogeneous structure. On a transverse section it revealed plate-like sections (rarely undulated in transverse section) of the future polar filament, with a dark inside, bearing on the surface fine ridges appearing as sectioned microtubules set $12.5 \mathrm{~nm}$ apart (Figs. 9, 10). In longitudinal section the filament appeared as an irregularly wound structure reaching outside through the filament discharge canal. The narrow layer of the remnant of capsulogenic cell was squeezed between the rather thin dense layer of the capsule wall, while the lucent layer, known to be chitinous (Lukeš et al. 1993), was about $0.23 \mu \mathrm{m}$ thick.

$\mathrm{T}$ y p e a n d o n ly hos t: Heteroclinus whiteleggii (Ogilby, 1894) (Perciformes: Clinidae).

Type 1 o c a 1 it y: Arrawara, New South Wales, Australia.

Site of infection: Gallbladder.

Prevale n c e : $50 \%$ (2 fish infected / 4 fish examined).

T y p e mate r i a 1: Phototypes deposited in the Institute of Parasitology, Academy of Sciences of the Czech Republic, České Budějovice, no. PT 7001.

$\mathrm{E} \mathrm{t} \mathrm{y} \mathrm{mol}$ o g y : The new species is named in honour of Elmer R. Noble, the eminent American parasitologist known also for his studies on Myxosporea.

\section{DISCUSSION}

\section{Identity of the species}

Out of the 37 Sphaeromyxa species recorded to date, only about 6 species have an arched spore with the two valves equally long. None of these species has a host that lives in the Pacific Ocean at the Australian coast all live either near Japan or in the Atlantic or Indian Ocean. Their hosts also belong to different orders of fish except for Pholis pictus, host of S. parva Dogiel, 1948 from the Japan Sea. S. parva, however, is smaller in its dimensions (only 15 to $17 \mu \mathrm{m}$ in length), and the spore is essentially less arched than that of the Sphaeromyxa noblei. S. cottidarum Dogiel, 1948, except for different hosts (scorpaenid fishes) and their different area of distribution (Japan Sea, Bering Sea and Atlantic Ocean), has considerably longer spores $(33-35 \mu \mathrm{m})$. S. elegini Dogiel, 1948, except for a different host (Eleginus gracilis) with a different area of distribution (Japan Sea, Bering Sea), has a spindle-shaped spore only slightly arched, unlike S. noblei. S. exneri Awerinzew, 1913 also 


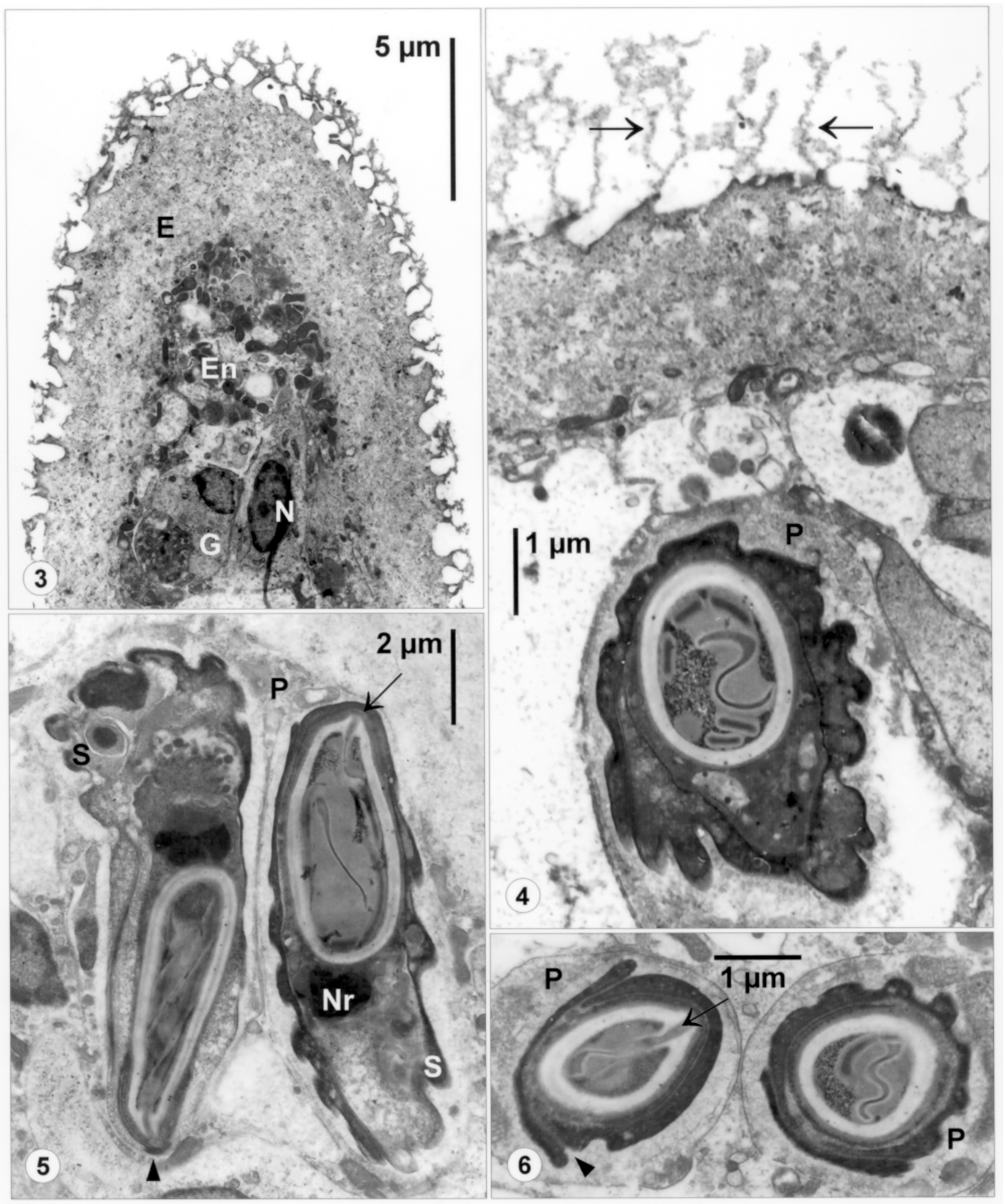

Figs. 3-6. Sphaeromyxa noblei sp. n., transmission electron micrographs. Fig. 3. Edge of the plasmodium covered with small projections bearing mucous strands. E - ectoplasmic layer; En - endoplasm with various cell inclusions, generative cells $(G)$ and somatic nuclei (N). Fig. 4. Part of the periphery of the plasmodium with a nascent spore with an immature polar capsule in the pansporoblast $(\mathrm{P})$; arrows point at the surface mucous strands. Fig. 5. A pair of obliquely sectioned immature spores within a common pansporoblast $(\mathrm{P}) ; \mathrm{S}$ - shell valve; $\mathrm{Nr}$ - dense mass representing the residual capsulogenic nucleus; arrow points at the point of exit of the polar filament through the capsular wall; arrowhead marks the dense cap on the filament discharge pore. Fig. 6. Section through two spore ends with almost mature polar capsules, both in monosporic pansporoblasts (P). Arrow points at the discharge canal of the polar filament; note the way in which one shell valve is embracing the other (at that point wider) valve (arrowhead). 


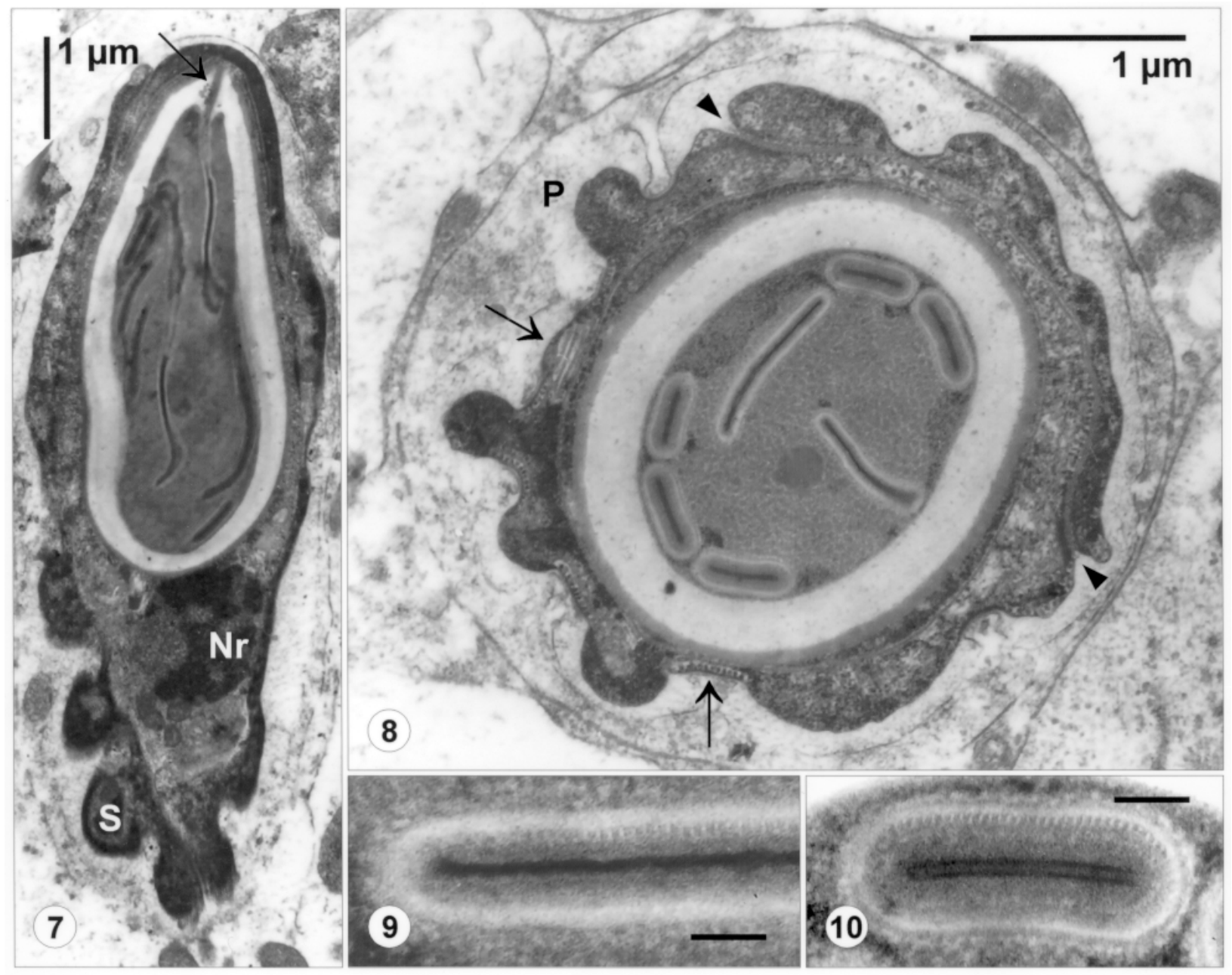

Figs. 7-10. Sphaeromyxa noblei sp. n., transmission electron micrographs. Fig. 7. Section through an almost mature spore with coils of the polar filament still in formation. Arrow points at the narrow discharge canal for the flat filament; $\mathrm{Nr}-\mathrm{residual} \mathrm{nu-}$ cleus of the capsulogenic cell; S - shell valve. Fig. 8. Transverse section through the end of spore at the level of the polar capsule with coils of the almost mature polar filament in the dark capsular matrix. P - pansporoblast harbouring a single spore; arrowheads point at the junction of one shell valve covering the other; arrow points at the microtubules in the longitudinal furrow of the shell. Figs. 9, 10. Enlarged transverse sections of polar filament parts from Fig. 8; note the dark inner lining of the flat filament lumen and fine ridges of the surface of the filament. Scale bars: Figs. 9, $10=100 \mathrm{~nm}$.

lives in a different host (a scorpaeniform fish of the family Agonidae) with a different area of distribution (Japan Sea and Indian Ocean) and has only slightly arched spore shape. S. hellandi has considerably longer spores $(20-26 \mu \mathrm{m})$ and lives in a gadid fish and though it was also reported from a perciform fish, it was from a different family (Pholidae). S. hexagrammi Dogiel, 1948 differs in living in different hosts (scorpaenid fishes in Japan Sea) and has slightly shorter spores (average $18 \mu \mathrm{m}$ ). S. solomoni Aseeva, 2002 from different hosts and Japan Sea has longer spores (25-27.5 $\mu \mathrm{m})$. Although this account does not take into consideration the properties of the plasmodium (often disregarded), we can take for granted that the species under study is a new species.
We attach a list of Sphaeromyxa species at the end of the discussion, since according to our records the recent list of Aseeva (2002) is not complete. Browsing through the list, one can only wonder in how different hosts even in different orders - some species of this genus live. This especially applies to $S$. balbianii; if all records really represent one species, which should be supported by molecular proof, it indicates an extremely low host specificity. The list also shows how little is the genus known - few of the species have been recorded more than once.

\section{Ultrastructural comparison}

The mucous "branches", identifiable with glycostyles, covering the surface of the plasmodium, are a 
rather rare feature in myxosporean plasmodia. Grassé and Lavette (1978) did not observe any remarkable cell coat in S. sabrazesi, while in S. balbianii Gracia et al. (1997) recorded a horizontal mucus layer, perhaps of plasmodial origin, touching the tips of the cell projections. In very few myxosporean species there exist similarly elaborate, glycostyle-like structures like in $S$. noblei. Thus at the surface of the histozoic plasmodium of Myxobolus disparoides there are pyramidal structures about $0.3 \mu \mathrm{m}$ high composed of several layers (Uspenskaya 1984); tiny stratified tubercles are also on the surface of plasmodia of Thelohanellus pyriformis in blood vessels of tenches (Dyková and Lom 1987). In plasmodia of other species, the cell coat, if present at all, has the value of nanometres, not micrometres. Thus in the histozoic plasmodium of Henneguya adiposa the cell coat is about $80 \mathrm{~nm}$ thick (Current 1979); in M. funduli the granular cell coat is about $60 \mathrm{~nm}$ thick (Current et. al 1979), and coelozoic plasmodia of Myxidium lieberkuehni have a very thin layer of cell coat (Lom and de Puytorac 1965). Curiously, the surface of spores of Henneguya pilosa bears cell coat digitiform differentiations (Azevedo and Matos 2003); here these structures may serve for better buoyancy of spores in water. Factors that elicit the occurrence of different degree of cell coat development in plasmodia, however, have yet to be discovered.

The fine microtubule-like ridges on the surface of the nascent polar filament have a spacing $(12.5 \mathrm{~nm})$ similar to analogous structures on other filaments in myxosporean and actinosporean stages, where the spacing averages 11 to $12 \mathrm{~nm}$ (Lom and Dyková 1997) and also exemplifies the structural unity of these organisms.

Although only scarce data have been obtained on the fine structure of the genus Sphaeromyxa (Lom 1969, Grassé and Lavette 1978, Uspenskaya 1982, Gracia et al. 1997, the present paper), it appears that the structure of its species follows the same pattern: plasmodia have marked surface projections; the endoplasm is full of extremely large vacuoles; the lobocytes, absent in other genera, are of common appearance; and sections through polar capsule reveal different appearance of subsequent stretches of the polar filament unlike in other Myxosporea. The separateness of this genus should be confirmed by molecular analysis, which we - because of shortage of material - could not perform.

\section{List of species of the genus Sphaeromyxa}

(in alphabetical order, host species names follow mostly the original sources)

S. arcuata Fantham, 1930

Macroplus nasutus, Bathygobius soporator, Argyrozona argyrozona; Atlantic Ocean off Namibia; Fantham 1930

S. argentinensis Timi et Sardella, 1998
Engraulis anchoita; South-west Atlantic, Argentine Sea; Timi and Sardella 1998

S. atherinae Karataev et Iskov, 1984 Atherina mochon pontica; Black Sea; Karataev and Iskov 1984

S. balbianii Thélohan, 1892 - type species Alosa sardina, Blennius pavo, B. sanguinolentus, Cepola macrophthalma, Chaetodon hoefleri, Clupea pilchardus, Epigonus denticulatus, Gobius angolensis, Syngnathus floridae, S. louisianae, Taurocottus bergi, Triglops murrazi, Xenodermichthys copei, Abudefduf marginatus, Sardinella maderensis; Adriatic Sea, Mediterranean Sea, Black Sea, Atlantic Ocean, Pacific Ocean, Japan Sea; Thélohan 1892, Davis 1917, Kudo 1919, Lom 1969, Khan et al. 1986, Jurachno 1988, Lubat et al. 1989, Kovaljova et al. 1993, Kpatcha et al. 1996, Gracia et al. 1997

S. bonaerensis Timi et Sardella, 1998 Anchoa marini; South-west Atlantic, Mar del Plata Port; Timi and Sardella 1998

S. cottidarum Dogiel, 1948

Hemitripterus villosus, Enophrys diceraus, Enophrys sp., Blepsias sp.; Atlantic Ocean, Bering Sea, Japan Sea; Dogiel 1948, Shulman 1966

S. curvula Fantham, 1930

Helicolenus dactylopterus, Pachymetopon blochii; Atlantic Ocean off Namibia; Fantham 1930

S. dighae Sarkar et Majumder, 1983

Hilsa ilisha; Bay of Bengal; Sarkar and Majumder 1983

S. elegini Dogiel, 1948

Eleginus gracilis; Japan Sea, Bering Sea; Dogiel 1948, Shulman 1966

S. exneri Awerinzew, 1913

Thrysanophrys japonicus, Sarritor leptorhynchus; Indian Ocean (Mosambique Channel), Japan Sea; Awerinzew 1913, Kudo 1919

S. ganapatii Kalavati et Vaidehi, 1991

Terapon jarbua; Chilka Lake, India; Kalavati and Vaidehi 1991

S. gasterostei Georgévitch, 1916

Gasterosteus spinachia; Mediterranean Sea; Georgévitch 1916, Kudo 1919

S. gibbonsia Noble, 1939

Gibbonsia elegans, G. metzi; Pacific Ocean; Noble 1939

S. hareni Sarkar, 1984

Tachysurus platystomus; Bay of Bengal; Sarkar 1984

S. hellandi Auerbach, 1909

Pholis gunellus, Molva molva, Brosme brosme, Merlangius merlangus; Atlantic Ocean, Barents Sea; Auerbach 1909, Kudo 1919, Shulman 1966, Kalavati and MacKenzie 1999

S. hexagrammi Dogiel, 1948

Hexagrammus octogrammus, H. stelleri, Pleurogrammus azonus; Japan Sea; Dogiel 1948, Shulman 1966 
S. incurvata Doflein, 1898

Blennius ocellaris, Solea lascaris nasuta; Mediterranean Sea, Black Sea; Doflein 1898, Kudo 1919

S. intermediata Moser et Noble, 1977

Malacocephalus occidentalis, Nezumia cyrano, Ventrifossa macropogon, V. mucocephalus; Caribbean Sea; Moser and Noble 1977

S. japonica Aseeva, 2002

Triglops scepticus, T. jordani, Eurymen gurinus; Japan Sea; Aseeva 2002

S. lateralis Noble, 1941 Artedius lateralis; Pacific Ocean; Noble 1941

S. lomi Moser et Noble, 1977

Malacocephalus occidentalis; coast of Borneo Island; Moser and Noble 1977

S. longa Dunkerly, 1921

Gadus minutus; off Plymouth, England; Dunkerly 1921

S. magna Zhukov, 1964

Liparis gibbosus; Bering Sea; Zhukov 1964, Shulman 1966

S. maiyai Morrison et Pratt, 1973

Microgadus proximus; Oregon Coast of Pacific Ocean; Morrison and Pratt 1973

S. minuta Polyanskii, 1955

Hippoglossus hippoglossus; Barents Sea; Polyanskii 1955, Shulman 1966

S. nesogobii Su et White, 1994

Nesogobius sp.; West Pacific, Tasmania; Su and White 1994

S. noblei $\mathrm{sp} . \mathrm{n}$.

Heteroclinus whiteleggii; coast of New South Wales, Australia

S. opisthopterae Sarkar, 1999

Opisthopterus tardoore; Bay of Bengal; Sarkar 1999

S. ovula Noble, 1939

Arbaciosa rhessodon; Santa Barbara coast, California; Noble 1939
S. parva Dogiel, 1948

Cololabis saira, Pholis pictus; Japan Sea; Dogiel 1948, Shulman 1966

S. pultai Tripathi, 1953

Odontoamblyopus rubicundus; Bay of Bengal; Tripathi 1953

S. reinhardti Jameson, 1929

Engraulis mordax; Pacific Ocean; Jameson 1929

S. sabrazesi Laveran et Mesnil, 1900

Hippocampus brevirostris, H. guttulatus, Syngnathus acus, Motella tricirrata; Mediterranean Sea, Atlantic Ocean; Laveran and Mesnil 1900, Kudo 1919

S. schulmani Kovaljova et Gaevskaya, 1982

Salilota australis; South-west Atlantic; Kovaljova and Gaevskaya 1982

S. sevastopoli Naidenova, 1970

Neogobius fluviatilis, N. melanostomus, Proterorhinus marmoratus, Mesogobius batrachocephalus; Black Sea, Azov Sea, St. Clair River and Lake St. Clair (USA); Naidenova 1970, Miroshnichenko 1984, Pronin et al. 1997

S. solomoni Aseeva, 2002

Gymnocanthus pistilliger, Enophrys dicerus; Japan Sea; Aseeva 2002

$S$. theraponi Tripathi, 1953

Therapon jarbua; Indian Ocean; Tripathi 1953

S. tripterygii Laird, 1953

Forsterygion varium, Bellapiscis medius; off New Zealand; Laird 1953, Hewitt and Hine 1972

Acknowledgements. Thanks are due to Prof. Klaus Rohde, who made possible the author's stay at the Arrawara biological station, where the material was collected. The research was supported by the grant no. AV0Z6022909 from the Academy of Science of the Czech Republic. Invaluable editorial assistance of Dr. Vladimír Bukva is sincerely appreciated.

\section{REFERENCES}

ASEEVA L.N. 2002: New species of myxosporeans (Myxozoa, Myxosporea) from sculpins of the northwestern Japan Sea. Acta Parasitol. 47: 179-189.

AUERBACH M. 1909: Bemerkungen über Myxosporidien. Zool. Anz. 34: 65-82.

AWERINZEW S. 1913: Ergebnisse der Untersuchungen über parasitischen Protozoen der tropischen Region Afrikas. III. Zool. Anz. 42: 151-156.

AZEVEDO C., MATOS E. 2003: Fine structure of Henneguya pilosa sp. n. (Myxozoa: Myxosporea), parasite of Serrasalmus altuvei (Characidae), in Brazil. Folia Parasitol. 50: 35-40.

CURRENT W.L. 1979: Henneguya adiposa Minchew (Myxosporida) in the channel catfish: ultrastructure of the plasmodium wall and sporogenesis. J. Protozool. 26: 209-217.

CURRENT W.L., JANOVY J., Jr., KNIGHT S. 1979: Myxosoma funduli Kudo (Myxosporida) in Fundulus kansae ultrastructure of the plasmodium wall and of sporogenesis. J. Protozool. 26: 574-583.

DAVIS H.S. 1917: The Myxosporidia of the Beaufort Region. A systematic and biological study. Bull. Bur. Fish. 35: 201-243.

DOFLEIN F. 1898: Studien zur Naturgeschichte der Protozoen. III. Über Myxosporidien. Zool. Jahrb., Anat. 2, 11: 281-350.

DOGIEL V.A. 1948: [Parasitic Protozoa of the fish of Peter the Great Bay.] Izv. Vsesoyuz. Nauchno-Issled. Inst. Ozern. Rechn. Khoz. 27: 17-66. (In Russian.)

DUNKERLY J.S. 1921: Fish Myxosporidia from Plymouth. Parasitology 12: 328-333.

DYKOVÁ I., LOM J. 1987: Host cell hypertrophy induced by contact with trophozoites of Thelohanellus pyriformis (Myxozoa: Myxosporea). Arch. Protistenkd. 133: 285293. 
FANTHAM H.B. 1930: Some parasitic protozoa found in South Africa, XIII. S. Afr. J. Sci. 27: 376-390.

GEORGÉVITCH J. 1916: Note sur les Myxosporidies recuellis à Roscoff. Bull. Soc. Zool. Fr. 41: 86-95.

GRACIA M.P., MAÍLLO P.A., AMIGÓ J.M., SALVADÓ H. 1997: Ultrastructural study of Sphaeromyxa balbianii Thélohan, 1892 (Myxozoa, Myxosporea: Bivalvulida), a parasite of Cepola macrophthalma Linnaeus, 1758. Acta Protozool. 36: 171-179.

GRASSÉ P.-P. 1960: Les Myxosporidies sont des organismes pluricellulaires. C. R. Acad. Sci. (Paris) 251: 2638-2640.

GRASSÉ P.-P., LAVETTE A. 1978: La myxosporidie Sphaeromyxa sabrazesi et le nouvel embranchement de Myxozoaires (Myxozoa). Recherches sur l'état pluricellulaire primitif et considerations phylogénetiques. Ann. Sci. Nat., Zool. (Paris) 2: 193-285.

HEWITT G.C., HINE P.M. 1972: Checklist of parasites of New Zealand fishes and of their hosts. N.Z. J. Mar. Freshwater Res. 6: 69-114.

JAMESON A.P. 1929: Myxosporidia from Californian fishes. J. Parasitol. 16: 59-68.

JURACHNO V.M. 1988: New data on fish Myxosporea of the Black Sea. Parazitologiya 22: 521-524.

KALAVATI C., MacKENZIE K. 1999: The genera Ceratomyxa Thélohan, 1892, Leptotheca Thélohan, 1895 and Sphaeromyxa Thélohan, 1892 (Myxosporea: Bivalvulida) in gadid fish of the northeast Atlantic. Syst. Parasitol. 43: 209-216.

KALAVATI C., VAIDEHI J. 1991: Two new species of myxosporidians from fishes of Chilka Lake: genus Sphaeromyxa Thélohan and genus Zschokkella Auerbach. Uttar Pradesh J. Zool. 11: 146-150.

KARATAEV A.K., ISKOV M.P. 1984: New Myxosporidia species from Black Sea sand-smelt Atherina mochon pontica. Vestn. Zool. 1984 (1): 59-60.

KHAN R.A., BOWERING W.R., BURGEOIS C., LEAR H.P., PIPPY J.H. 1986: Myxosporean parasites of marine fish from the continental shelf of Newfoundland and Labrador. Can. J. Zool. 64: 2218-2226.

KOVALJOVA A.A., GAEVSKAYA A.V. 1982: New data on Myxosporidia from the south-western Atlantic fishes. Parazitologiya 16: 353-359. (In Russian.)

KOVALJOVA A.A., VELEV P., VLADEV P. 1993: New data on myxosporidians (Cnidospora: Myxosporea) fauna from commercial fishes of the Atlantic coast of Africa. In: Ecology and resources of commercial fishes of the eastern Atlantic. AtlantNIRO, Kaliningrad, 174-193. (In Russian.)

KPATCHA T.K., DIEBAKATE C., TOGUEBAYE B.S. 1996: Myxosporidia (Myxozoa, Myxosporea) of the genera Sphaeromyxa Thélohan, 1892, Myxidium Bütschli, 1882, Zschokkella Auerbach, 1910, Bipteria Kovaljova, Zubtchenko \& Krasin, 1983 and Leptotheca Thélohan, 1895 parasites of fish from the coast of Senegal (West Africa). J. Afr. Zool. 110: 309-317.

KUDO R.R. 1919: Studies on Myxosporidia. Ill. Biol. Monogr. 5: 1-265.

LAIRD M. 1953: The Protozoa of New Zealand intertidal zone fishes. Trans. R. Soc. N. Z. 81: 79-143.

LAVERAN A., MESNIL F. 1900: Sur une Myxosporidie des voies biliaires de l'Hippocampe (Sphaeromyxa sabrazesi nov. sp.). C. R. Soc. Biol. Paris 52: 380-382.
LOM J. 1969: Notes on the ultrastructure and sporoblast development in fish parasitising myxosporidian of the genus Sphaeromyxa. Z. Zellforsch. 97: 416-437.

LOM J., DYKOVÁ I. 1997: Ultrastructural features of the actinosporean phase of Myxosporea (phylum Myxozoa): a comparative study. Acta Protozool. 36: 83-103.

LOM J., de PUYTORAC P. 1965: Studies on the myxosporidian ultrastructure and polar capsule development. Protistologica 1: 53-65.

LUBAT V., RADUJKOVIĆ B., MARQUES A., BOUIX G. 1989: Parasites des poissons marins du Montenegro: Myxosporidies. Acta Adriat. 30: 31-50.

LUKEŠ J., VOLF P., LOM J. 1993: Detection of chitin in spores of Myxobolus muelleri and M. subepithelialis (Myxosporea, Myxozoa). Parasitol. Res. 79: 439-440.

MIROSHNICHENKO A.I. 1984: Mixosporidia [sic] of the fishes of Crimea. Vestn. Zool. 1984 (6): 16-22.

MORRISON N.D., PRATT I. 1973: Sphaeromyxa maiyai sp. n. (Protozoa: Myxosporidea), coelozoic parasite of the Pacific tomcod Microgadus proximus. J. Protozool. 20: 214-217.

MOSER M., NOBLE E.R. 1977: Three genera of myxosporida (Protozoa) in macrourid fishes. Int. J. Parasitol. 7: 93-96.

NAIDENOVA N.N. 1970: Parasitofauna of fishes from family Gobiidae from the Azov Sea. Biol. Morya 20: 84-113. (In Russian.)

NOBLE E.R. 1939: Myxosporidia from tide pool fishes of California. J. Parasitol. 25: 359-364.

NOBLE E.R. 1941: On the distribution relationships between California tide pool fishes and their myxosporidian (protozoan) parasites. J. Parasitol. 27: 409-415.

POLYANSKII Yu.I. 1955: On parasitology of fishes from the northern seas of the USSR. Parasites of fishes from the Barents Sea. Proc. Zool. Inst. Acad. Sci. USSR 19: 5-170. (In Russian.)

PRONIN N.M., FLEISCHER G.W., BALDANOVA D.R., PRONINA S.V. 1997: Parasites of the recently established round goby (Neogobius melanostomus) and tubenose goby (Proterorhinus marmoratus) (Cottidae) from the St. Clair River and Lake St. Clair, Michigan, USA. Folia Parasitol. 44: $1-6$.

SARKAR N.K. 1984: A new myxosporidan Sphaeromyxa hareni sp. n. (Myxozoa: Myxididae) from an Indian marine teleost Tachysurus platystomus (Day). Acta Protozool. 23: 183-186.

SARKAR N.K. 1999: Ortholinea gadusiae sp. n. and Sphaeromyxa opisthopterae sp. n. (Myxozoa: Myxosporea) from the clupeid fish of the Bay of Bengal, West Bengal, India. Acta Protozool. 38: 145-153.

SARKAR N.K., MAJUMDER S.K. 1983: Myxosporidian Sphaeromyxa dighae sp. n. (Myxozoa: Myxidiidae) from the gallbladder of Hilsa ilisha (Clupeidae). Acta Protozool. 22: 257-260.

SHULMAN S.S. 1966: Myxosporidia of the USSR. Izd. Nauka, Akad. Sci. USSR, Moskva-Leningrad, 504 pp. (In Russian.)

SU X.-G., WHITE R.W.G. 1994: New myxosporeans (Myxozoa: Myxosporea) from marine fishes of Tasmania, Australia. Acta Protozool. 33: 251-259. 
THÉLOHAN P. 1892: Observations sur les myxosporidies et éssai de classification de ces organismes. Bull. Soc. Philom. 4: 165-178.

TIMI J.T., SARDELLA N.H. 1998: Myxosporeans and coccidians parasitic on engraulid fishes from the coasts of Argentina and Uruguay. Parasite 5: 331-339.

TRIPATHI Y.R. 1953: Studies on parasites of Indian fishes. I. Protozoa Myxosporidia together with a check list of parasitic protozoa described from Indian fishes. Rec. Indian Mus. 50: 63-88.
USPENSKAYA A.V. 1982: Ultrastructure of the polar apparatus of the myxosporidian Sphaeromyxa cottidarum. Tsitologiya 14: 779-782. (In Russian.)

USPENSKAYA A.V. 1984: [Cytology of Myxosporidia.] Nauka, Leningrad, 112 pp. (In Russian.)

ZHUKOV E.V. 1964: On the parasite fauna of the fishes of the Chukotsk peninsula and the adjoining seas. III. The parasitic Protozoa of marine and freshwater fishes. Parazitol. Sb. 22: 224-263. (In Russian.) 